\title{
Simple macro aggregate transport demand modelling in river transport study
}

\author{
R.Didin Kusdian ${ }^{1, *}$ \\ ${ }^{1}$ Sangga Buana YPKP University, Department of Civil Engineering, Bandung, Indonesia
}

\begin{abstract}
Sustainability and development of river transport can reduce the burden of road transport, where the development of road transport requires clearing new land is increasingly expensive and development is quite expensive. To estimate the amount of potential movement of people and goods through river mode choice model can be derived based on a comparison of risk at each mode, whereby the greater the risk will be even smaller portion of the mode selected. From the results of the model calculation of the aggregate distribution modes, obtained through a portion of the potential movement of the Batang Hari river in Jambi, Sumatra Island, Indonesia is $13,89 \%$ for the movement of people and $14.85 \%$ for goods.
\end{abstract}

\section{Introduction}

At least not in the last five years has conducted studies on the potential transport stream continues in Indonesia, and until now has not been around the area that have the potential transport streams surveyed and analyzed potential. Some rivers that have been the object of research include Indragiri River, River Seputih, Onion River Bones, Mesuji River, River Sekampung, Batang River (on the island of Sumatra), the Barito River, River cascade Right, Left cascade river, Amandit river, Sungai Batang Alai, Tabalong River Left, Right Tabalong River, River Tapin, Amandit River, River Balangan, Melawi River, Pawan River, River Sambas, Kendawangan River, Porcupine River, the River Kapuas, Mahakam River, River Sesayap, Kayan River, River Sembakung (in Borneo Island) [1].

If viewed from the side of the history of the movement of people across the region in line with the time line of the history of civilization and technological development of transportation, will be remembered that it used the transport stream earlier than other types of transportation in the world.

Advances in technology and the development of infrastructure construction vehicle motion media vehicles have gradually eliminate vehicle transport water through the river to reach the center of activity in the mainland, where the movement of tangible media stream to connect to the port on the coast as the gateway transportation between islands and even between continents.

\footnotetext{
* Corresponding author: kusdian@yahoo.com
} 
The rapid growth of industrial combustion four-wheeled vehicles and two-wheeler, has been welcomed by the traveling consumer uptake rapidly growing vehicle markets as well, one of the advantages that attract consumers is its 'door to door', making it easier for individuals to move and save time. But when it continues to grow, now arrived at a situation where the users of the road (motion media) each other have slowed down movement of vehicles which can be enjoyed respectively. The volume and density of vehicles on the road continues to increase, the frequency of the number of events increased congestion on the roads as well, especially in densely populated areas.

Maintenance, improvement, and construction of new lanes on road infrastructure cost which cannot be said to be cheap, the increased vehicle traffic will accelerate the deterioration of the road surface, damage to the road surface will also hinder the flow of vehicles that run on it. The situation above be positive reasons why river transport should be prevented from extinction, river water body is a medium that has been provided by the natural motion that should be utilized as a medium water movement of vehicular traffic. With the use of the river as a media vehicle motion is expected that the distribution of the load the vehicle is moving, so that the density can be reduced, or the need for emergency opening of land for widening and the addition of new roads could be reduced [2].

The transfer of the vehicle into the river, especially for goods vehicles, that certain types of goods, such as commodities or raw materials such as energy crops rubber, palm oil and coal mining [3]. Sure to other types of commodities can be further investigated. Many aspects of research that needs to be done regarding the possibility of sustainable development of river transportation, few studies have been conducted by the author work well in a team as well as involvement in individually.

Among those who have begun to put forward the result is about how the sustainability of the system using a traditional cruise ship review the point of timber to the Port of Sunda Kalapa [3], the issues raised in this study is that the use of timber ships will be threatened to stop due to increasing scarcity and increasingly difficult, even impossible, to obtain a special wooden materials suitable for building ships, namely ironwood. But then submitted that this does not mean that the activities of traditional community-based transportation system, it should cease to operate as part of the national transportation system in Indonesia. Still need further study how the sustainability of the system and the organization of community-based shipping operations, although not using timber ship again.

To be more purposeful planning follow-up policy development and construction management on a river cruise system, aspects of the required study and apply the result is about how to estimate quantitatively the potential movements using river transportation system. In this paper aspects of modeling to estimate the potential amount of movement needs to use river transportation, particularly the movement of goods, a major topic of discussion and debate.

\section{Methodology}

This paper is part of research results by using a combined method of field surveys, literature surveys, and continuous analysis of the study reports based sectoral government and university research-based studies. The establishment of the model through a process of formulating a model phenomenon that formed sentences that fit the logic and common sense, then lowered into the mathematical model, then the mathematical model implemented in the EXCEL computer program package and analyzed again according to common sense and observations in the real world, or field, in this case in the cities that passed the flow of the great river, the city of Jambi in Sumatra and Kalimantan's Kutai Kartanegara City, both in Indonesia. 


\section{Data collection}

The data in the background of the discussion contained in this paper is comprised of a team of survey data, data from personal observations of the author and secondary data sourced from Indonesia's national statistical agencies and data from previous research reports and studies, both project-based sectoral government (Ministry of Transport of the Republic of Indonesia and the Ministry of Public Works), as well as university-based research project (Directorate General of Higher Education Ministry of National Education Republic of Indonesia).

\section{Modeling potential need transportation planning through movement for river}

Modeling the movement needs to transport planning is an approach to phenomena involving spatial, population activities in the region, and the movement of people and / or goods vehicle over a network using motion media or vehicles that have been built over the area modeled for the area concerned. Based approach to modeling done by the system, the system boundary is a boundary where space area region. Sub space systems area is the area fractions within the area is termed the zone.

Movement is modeled with a matrix-based. So, in the process will occur interplay or interaction between the zones. Approach such a system closer to reality than the simpler approach of segment-based motion media. Terminology model into the main frame of the study was a Phase Four Transportation Planning Model.

The model consists of the generation phase of the movement-the movement of the distribution phase-phase mode selection-stage route or traffic loading [4].

\subsection{Available data movement requirements}

As mentioned above, when the study was conducted previously done modeling work and planning that has resulted in estimates of movement between the zones in the basin that were reviewed, the origin destination matrix between the zones. But from previous reports that exist, have not discussed the details of how the amount of movement of goods using river transport. This amount is considered in this study as a potential, where the numbers need to be estimated.

For that needs to be made between the model estimates the distribution of movement through motion media road and through motion media streams with vehicles such as boats or river boats.

\subsection{Establishment division of mental models moda}

The definition of mental models of the way of thinking here is the statement formed in the sentence in accordance with its meaning or logical reason. The statements formulated in this regard is that generally describes how transport users will prefer to use certain kinds of modes based on their characteristics. Model established in this study is a macro model that is aggregated.

That is the tendency to choose a group rather than individually. Requirements modeling is faced for the sake of space-based planning or region, which has been divided into small parts that zone. Data movement needs you have available is the data movement between the zones, without specifying the distribution for each mode of transportation. 
Each of these modes, i.e. modes of trucks by road and boat modes through the river, will have attributes viewed as obstacles or risks trips paid users.

Simple statement that applied at the macro and aggregate are:

1. Portions election of each mode in value such that the attributes or characteristics of the offered modes risks.

2. Comparison of a portion of the selection modes with other modes will be inversely proportional to the attributes or risks at each mode of transportation.

3. Number of servings election all modes of transport is $100 \%$.

\subsection{Moda distribution mathematical model postulations}

Researchers have tried several mathematical models to describe the mental models of the three items above, but in this paper will only put forward a model of the easiest and simplest way to describe the portion of the macro is the selection of aggregate, which can be expressed mathematically by equation (1)

$$
P m=(1 / R m) /[\Sigma(1 / R m)]
$$

Where:

$P m=$ portion of the selected mode $\mathrm{m}$

$R m=$ the amount of risk offered modes $m$

This model applies to straight mileage identical for each mode, where the risk is offered modal travel time and vehicle operating costs. If the same origin-destination of the infrastructure mode and other modes differ in the distance, according to the distance of each motion media, it needs to be taken into account proximity correction

\subsection{Test of mode distribution mathematical model with artificial data}

The model that has been postulated as in equation (1) in section 4.3, before being applied to the case of actual planning, need to be tested with artificial numerical data in order to know if it is in accordance with the mental model formulated in section 4.2. For this, the division will count the selected portion of the two modes are available in parallel lines in a region of space that can be used to move from one point of origin to a destination point movement of the same movement.

\subsection{Use of mathematical models for estimating distribution mode selected river transport potential}

From all the studies on the potential transport stream that has been done in Sumatra, Borneo, Java, and Papua, in Indonesia, it will not entirely be studied as an example of application in the real world for this paper. In this paper will only be presented in one court case, which is in the Batang Hari river which crosses the city of Jambi in Jambi Province, Sumatra,Indonesia.

\subsubsection{Identification of the number of modes}

Availability of premises available modes related infrastructure required for each mode of transport, as well as the pattern of freight business government and local communities. For the study area the last mode of transport are four types: motorcycles, private cars, public transport passenger cars, and the potential for passenger transport streams. As for the 
transport of goods only two modes are possible trucking of goods by road and transport goods by boat through the river.

\subsubsection{Identification of risk at each mode}

Risks that are offered by each mode may consist of more than one factor. For simplification model of the factors considered are the same factors present in each mode are just different scale numbers, and all units can be converted at the same time so it makes sense to be a factor. In the application of this mode selection model numbers used for comparison of risk is termed a combined risk

$$
R m=(T m . V t)+(F m . C f
$$

Where:

$R m=$ risk to offer a combined mode $\mathrm{m}$

$T m=$ time need by mode $\mathrm{m}$ for a distance of $1 \mathrm{~km}$ on motion media

$V t=$ value of time (taken equal for all modes)

$F m$ = fuel required mode $\mathrm{m}$ for a distance of $1 \mathrm{~km}$ on motion media

$C f=$ the price of fuel per $\mathrm{km}$ for each mode

\subsubsection{Mode choice model in straight river section parallel with roads}

In the simplest case can be exemplified for the state of infrastructure in the field with a condition in which the land and rivers or adjoining canals straight and parallel, for example, taken along the $1 \mathrm{~km}$, see Figure 2.

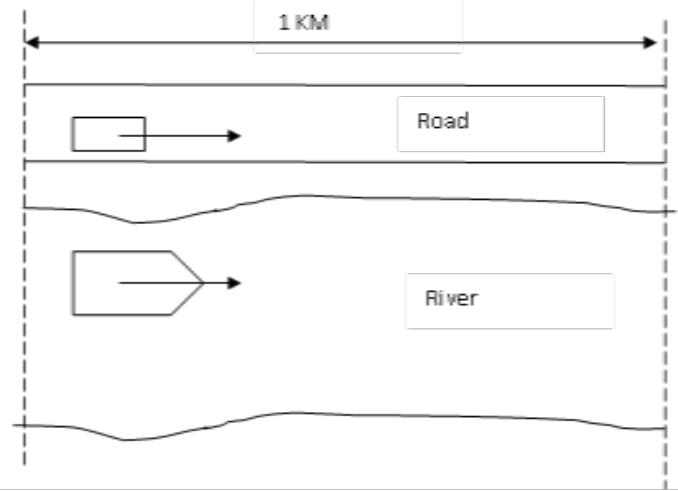

Figure 2. Case of $1 \mathrm{~km}$ parallel segment of road and river

Model calculations to include the risk of the price scale as indicated in section 4.6.2 above, was selected to produce a portion of each of the transport modes as shown in Table 1 , and for the transport of goods are listed in Table 2.

Table 1. Mode sharing for passenger transport

\begin{tabular}{|c|c|c|c|}
\hline Mode (m) & $\mathbf{R m}$ & $\mathbf{1 / R m}$ & $\mathbf{P m}$ \\
\hline Passenger Boat & $3.699,78$ & 0,00027 & $26,79 \%$ \\
\hline Motor Cycle & $5.500,03$ & 0,000182 & $18,02 \%$ \\
\hline Private Car & $5.500,05$ & 0,000182 & $18,02 \%$ \\
\hline Public Mini Bus & $2.666,67$ & 0,000375 & $37,17 \%$ \\
\hline & $\sum(\mathbf{1} / \mathbf{R m})$ & 0,001009 & $100,00 \%$ \\
\hline
\end{tabular}


Table 2. Mode sharing for freight transport

\begin{tabular}{|l|r|r|r|}
\hline \multicolumn{1}{|c|}{ Mode (m) } & \multicolumn{1}{c|}{ Rm } & \multicolumn{1}{c|}{$\mathbf{1 / R m}$} & \multicolumn{1}{c|}{ Pm } \\
\hline Freight Boat & $3.919,11$ & 0,000255 & $28,34 \%$ \\
\hline Truck & $1.550,00$ & 0,000645 & $71,66 \%$ \\
\hline & $\sum(\mathbf{1} / \mathbf{R m})$ & 0,0009 & $100,00 \%$ \\
\hline
\end{tabular}

Variables declared to risk modes per $1 \mathrm{~km}$ as has been previously calculated, need to be corrected by calculating the actual distance to the point of origin and the point of common purpose pursued by their respective modes. The real risk is multiplied by the actual distance corresponding geometric conditions within the media path motion. Having calculated by considering the actual distance to the sample segment as in Figure 3, obtained portions modal options as listed in Table 3 for passenger transport, and in Table 4 for transport of goods.

Table 3. Mode sharing for passenger transport with real geometric distance

\begin{tabular}{|c|c|c|c|}
\hline Mode (m) & $\mathbf{R m}$ & $\mathbf{1 / R m}$ & $\mathbf{P m}$ \\
\hline Passenger Boat & $8.392,80$ & 0,000119 & $13,89 \%$ \\
\hline Motor Cycle & $5.500,03$ & 0,000182 & $21,20 \%$ \\
\hline Private Car & $5.500,05$ & 0,000182 & $21,20 \%$ \\
\hline Public Mini Bus & $2.666,67$ & 0,000375 & $43,72 \%$ \\
\hline & $\sum(\mathbf{1} / \mathbf{R m})$ & 0,000858 & $100,00 \%$ \\
\hline
\end{tabular}

Table 4. Mode sharing for freight transport with real geometric distance

\begin{tabular}{|c|c|c|c|}
\hline Mode (m) & $\mathrm{Rm}$ & $1 / \mathrm{Rm}$ & $\mathrm{Pm}$ \\
\hline Freight Boat & $8.890,32$ & 0,000112 & $14,85 \%$ \\
\hline Truck & $1.550,00$ & 0,000645 & $85,15 \%$ \\
\hline & $\sum \mathbf{( 1 / R m )}$ & 0,000758 & $100,00 \%$ \\
\hline
\end{tabular}

\subsubsection{Estimation results number of quantitative potential river transport}

The approach estimates a portion of the selected mode is selected by multiplying the portion of each mode for each cell in the matrix OD matrix, this can be expressed by equation (3).

$$
\text { Tidm }=\text { Tid. Pm }
$$

Where:

Tid $=$ number of moves from the zone $\mathrm{i}$ into zone $\mathrm{d}$

Tidm $=$ number of moves from the zone $\mathrm{i}$ into the zone $\mathrm{d}$ using mode $\mathrm{m}$

$P m=$ portion of the selected mode $\mathrm{m}$

As the final results of the quantitative estimates of potential transport by river, the River Batanghari in Jambi Province, Sumatra, in Indonesia, is as shown in Table 13 for passenger transport and Table 5 for transport of goods. 
Table 5. OD matrix of passenger demand estimation for Batanghari River transportation (person/year)

\begin{tabular}{|c|c|c|c|c|c|c|c|c|c|c|c|c|c|}
\hline & $\begin{array}{l}\overline{\mathrm{g}} \\
\text { 든 } \\
\text { ș }\end{array}$ & 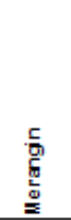 & $\begin{array}{l}5 \\
\frac{2}{2} \\
\frac{\pi}{0} \\
\text { o }\end{array}$ & 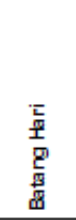 & 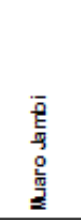 & 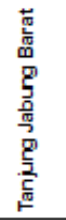 & 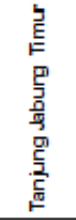 & 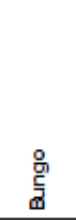 & 은 & $\begin{array}{l}\overline{0} \\
\text { ह } \\
\text { 旁 }\end{array}$ & 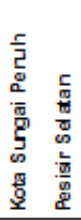 & $\frac{\text { 흥 }}{8}$ & 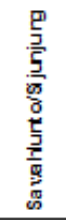 \\
\hline Kerinci & & & 1.235 & 882 & 964 & 532 & 475 & 2.188 & 975 & 1.623 & & $10 B 64$ & 5.615 \\
\hline Me rangin & & & 5.073 & 2525 & 2.189 & 1.318 & 1.179 & 3.887 & 1597 & 3. 947 & & 10630 & 6.633 \\
\hline Sarolangun & 1.688 & 5.333 & - & 2761 & 2.106 & 1.164 & 1.043 & 2.154 & 965 & 3.987 & & 6060 & 3.944 \\
\hline Bata ing Heri & 1.100 & 2.422 & 2.518 & - & 4.912 & 1.849 & 2.720 & 1.743 & 1365 & 11.780 & & 4955 & 3.520 \\
\hline Muaro Jam bi & 1.367 & 2.392 & 2.208 & 5647 & - & 3.857 & 4.511 & 1.957 & 2283 & 37.864 & & 7.431 & 5.335 \\
\hline Tanjung Ja bung Ba rat & 708 & 1.345 & 1. 130 & 1968 & 3.570 & - & 11.618 & 1.442 & 3023 & 6.430 & & 5702 & 4.258 \\
\hline Tanjung Jabung Timur & 478 & 913 & 788 & 2.197 & 3.188 & 8.817 & - & 874 & 1302 & 4. 328 & & 3387 & 2.443 \\
\hline Bungo & 3.019 & 4.105 & 2. 175 & 1929 & 1.884 & 1.500 & 1. 198 & - & 2504 & 3. 792 & & 13084 & 8.522 \\
\hline Tebo & 1.281 & 1.613 & 927 & 1.438 & 2.092 & 2993 & 1.699 & 2.383 & - & 4. 289 & & 9593 & 6.424 \\
\hline $\begin{array}{l}\text { Jambi } \\
\text { Kda Sungai Penuh } \\
\text { Pes Eir Selatan }\end{array}$ & 2.035 & 3.785 & 3.637 & 11780 & 32.934 & 6.042 & 5.367 & 3.426 & 4071 & - & & 9968 & 7.048 \\
\hline Solc & 11.46 & 8.79 & 4.788 & 427 & 5.575 & 4.622 & 3.617 & 10.19 & 7855 & 8. 596 & & - & 41.143 \\
\hline Sawahlunto/Sijunjung & 7.143 & 6.491 & 3.671 & 3592 & 4.735 & 4.081 & 3.087 & 7.856 & 6222 & 7. 189 & & 48674 & - \\
\hline
\end{tabular}

*City of Sungai Penuh and Pesisir selatan are not passed by the Batanghari River.

Table 6. OD matrix of freight demand estimation for Batanghari River transportation (ton/year)

\begin{tabular}{|c|c|c|c|c|c|c|c|c|c|c|c|c|c|}
\hline & है & 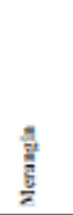 & 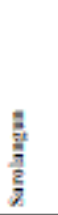 & 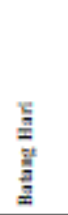 & $\begin{array}{l}\frac{\mathrm{z}}{\mathrm{z}} \\
\frac{\mathrm{E}}{\mathrm{E}} \\
\frac{\mathrm{z}}{\mathrm{z}} \\
\frac{\mathrm{n}}{2}\end{array}$ & 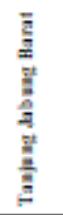 & 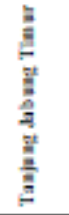 & 蛋 & $\stackrel{8}{\frac{8}{2}}$ & 를 & 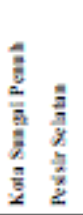 & $\frac{\overrightarrow{3}}{3}$ & 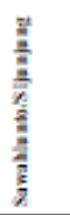 \\
\hline Kerixa & - & & 2406 & 1.308 & 1.609 & $1.1 \mathrm{S4}$ & 105 & 4218 & 1.446 & 2.421 & & 22.141 & 2993 \\
\hline Mkrsagin & & - & 2449 & 3950 & 4.351 & $244 s$ & 2.197 & 2757 & 3203 & 6.26 & & 18.276 & 1235 \\
\hline Serdagen & 2994 & 6786 & - & $4 \times 27$ & 4.01 & $1,4>$ & $1.2 \mathrm{ss}$ & 4003 & 1344 & 6.061 & & 7.68 & 2495 \\
\hline BuegFari & $209 \pi$ & 3999 & $\leq .145$ & - & $8 \cdot(\theta)$ & $3 J 8$ & 5.187 & 2611 & $18 \$ 9$ & 16.045 & & 9.449 & $6 \pi 2$ \\
\hline Agaro Janbi & $2.36 \theta$ & 3040 & 3317 & 2t3s & - & 5.349 & 7297 & 2713 & 3.064 & 43. 81 & & $12 \times 00$ & 2346 \\
\hline Tarjong Jabeng Burat & 934 & 2267 & 162 & 343 & 5.857 & - & 13.984 & 1.736 & 369 & 10.834 & & 6.863 & 6.147 \\
\hline Tarjong Jabeng Twur & $8 \pi$ & 2206 & 165 & 4727 & 7343 & 17514 & - & 1.59 & 2156 & 8.593 & & 8.409 & $4 \times 52$ \\
\hline Blago & 3844 & 6653 & $37 \pi$ & 2457 & 2.181 & 2288 & 158 & - & 3.479 & $4 \times 29$ & & 16.62 & 11840 \\
\hline Tobo & 2230 & 2504 & $1 \times 99$ & 2307 & 3.07 & 5201 & 3.179 & 4.142 & - & 8.027 & & 19.238 & 11.164 \\
\hline Jambi & 2933 & 145 & 3.844 & 16977 & 47.463 & 5800 & 7200 & $42 \times 9$ & $s 0 s s$ & - & & 14.363 & 8123 \\
\hline \multicolumn{14}{|l|}{$\begin{array}{l}\text { KocaSagiPaul } \\
\text { PezirirSdata }\end{array}$} \\
\hline Soldt & 2562 & $14 \times s 4$ & $\operatorname{ses} 9$ & 1063 & 12.946 & 1073 & 8998 & 21.982 & 1696 & 17.099 & & - & 102399 \\
\hline Sonzkhan/Sivaive & 14206 & 11.189 & 6815 & $\leq 239$ & 9.418 & 5953 & 4095 & 10417 & 12376 & $10.4 \times 6$ & & 77.448 & - \\
\hline
\end{tabular}

\section{Conclusion}

The conclusion from the above discussion can be summarized as follows:

1. The existence of large rivers are navigable on the larger islands, namely for Indonesia is Sumatra, Java, Borneo and Papua, should be used to preserve and develop water transportation system of the sea to the land.

2. Sustainability and development of river transport can reduce the burden of road transport, where the development of road transport requires clearing new land is increasingly expensive and development is quite expensive.

3. Reducing the burden of vehicle traffic on the road network caused by the division of the transport stream, especially for truck traffic, can reduce the cost of road maintenance. 
4. To estimate the amount of potential movement of people and goods through river mode choice model can be derived based on a comparison of risk at each mode, whereby the greater the risk will be even smaller portion of the mode selected.

5. If you have data available OD matrix, the OD matrix for each mode can be calculated by multiplying the mode selected portion of each scale matrix cells that expressed the amount of movement between zones pair of origin and destination zones. The number of potential movement using motion media streams, can be estimated by this method.

\section{Acknowledgements}

The author would like to thank the Directorate of Research and Community Services, the Directorate General of Higher Education, Ministry of National Education, Republic of Indonesia, roomates has funded this research through the National Strategic Research funding scheme, No. DIPA. 0541/023-04.1.01/00/2011, dated December 20, 2011, No. SP2H 104/SP2H/PL/Dit.Litabmas/IV/2011. dated 14 April 2012.

Also tank to the Directorate of Transport and Crossing the River, the Directorate of Land Transportation, Ministry of Communications REPUBLIC INDONESIA The author would like to thank the Directorate of Transport and Crossing the River, the Directorate of Land Transportation, Ministry of Communications of the Republic of Indonesia.

\section{References}

1. Kusdian, R. Didin, Borneo River Transportation Sustainability, in International Seminar on Regional Economic Development through Science, Technology, and Art Redstar, Medan Institute of Technology, pp. 1-10, (2012).

2. Kusdian, R. Didin, Potential Revitalization River Transport in Lampung Province, Journal of Transportation Studies Forum Transportation between Higher Education (FSTPT), Volume (8) Number 2, pp. 77-52, (2011) (in Indonesian).

3. Kusdian, R. Didin, Abubakar, Bakhtiar (2012), The Sustainability of Wooden Ships in Indonesia, Proceedings of "The Second International Conference on Port, Coastal, and Offshore Engineering (2nd ICPCO)", Bandung, 12-13 November 2012).

4. Tamin, Ofyar Z. Planning, Modeling, and Transportation Engineering, Theory, Sample Questions, and Applications, Publisher ITB, Bandung pp 74-80, pp 388-433 (in Indonesian), (2008)

5. Department of Transportation of the Republic of Indonesia, Study of River and Lake Transport Mode Potential Survey in West Sumatra Province and Jambi Province, Final Report (in Indonesian), (2012). 